\title{
Determination of the Rheological Properties of Red and White Bread Wheat Flours with Different
}

\section{Methods}

Pelin Dölek Ekinci ${ }^{1}$, Incilay Gökbulut ${ }^{2 *}$

${ }^{1}$ Sanlıurfa Wheat Exchange, Sanlıurfa, Turkey

2*Inonu University Faculty of Engineering Department of Food Engineering, Malatya, Turkey

\begin{abstract}
In this study, rheological properties of the bread wheat flour dough from 6 wheat genotypes were determined. For the pereparation of flour, 3 red bread (Pandas, Sagitorya, Pehlivan) and 3 white bread (Kaşifbey, Göktan, Ceyhan-99) were selected as wheat genotype. To determine the rheological properties of the wheat flour dough, farinograph, extensograph, mixolab and glutograph devices were used. According to the results of the Farinograph analysis, the average development time of wheat White and red genotypes were 1.95 minutes and 8.96 minutes, respectively. According to the extensograph results of the flour samples, the most extended stability value was determined with 7.47 min in Ceyhan-99 cultivar.

As a result of the research, it was determined that flour yields of red bread varieties were higher other genotypes, gas retention capacities of white bread flours were showed high result in extensograph application and resistance of dough to elongation was higher. In the Mixolab analysis, it determined that white bread wheat varieties have higher values in terms of kneading properties and gluten properties, and red bread wheat varieties have higher values in values of viscosity, amylase value and starch retrogradation.
\end{abstract}

Key words: Red bread wheat, white bread wheat, flour, rheological properties.

\section{Introduction}

Wheat is a cereal that provides an essential part of the daily calories and protein needed in human nutrition and constitutes the leading food of approximately $35 \%$ of the world population [1]. When wheat flour is mixed with water and turned into the dough, it forms a viscoelastic form. The gluten protein, which is responsible for the formation of the viscoelastic structure, has significant effects on the rheological properties of the dough during fermentation and mixing. The rheological properties of the wheat flour dough play an essential role in determining the flour quality and these properties affect both the workability of the dough and the quality of the final product. [2]. Measurement of elasticity value and rheological properties of flour dough such as elasticity, viscosity, extensibility are essential parameters for the bakery industry [3]. Various methods are available to measure the rheological properties of wheat flour dough [4]. Farinograph is an important device that gives 
information about the properties of the dough during kneading, water lifting capacity and breading properties of flour. It gives information about the rheological behavior of dough during kneading and dough, forming properties of gluten proteins. The flours to be used in bread production should have a high water-lifting force, while the kneading time is not too long. The short kneading time of flour dough indicates that the bread quality is generally low [1]. Stability of the flour dough is another parameter that indicates the processing resistance. The processing capacity of the doughs with short stability reduced at that rate and fermentation times are short. The low degree of softening in the Farinograph indicates that gluten proteins are intact [5].

Extensibility and resistance properties of flour dough are the critical parameters that provide essential information about the firing performance and end-product quality as well as determining the processability of wheat to different products [6]. These values can be determined using extensographs. The extensograph is one of measurement instruments used to determine the dough extensibility, kneading homogeneity, resting time, the effects of additives such as added salt, emulsifier, and oxidant on the structure and quality of the final product, as well as changes in dough during fermentation. The desired optimum extensibility values vary according to the product (bread, biscuit, noodles, etc). In bread making, high extensibility and resistance values are desired during the last fermentation and in the first stages of cooking. But, in the production of biscuits, low resistance values desired [2]. Mixolab is an important another device in flour industry, used to evaluate the processing quality of the flour dough, to measure physical properties such as strength and stability of the flour dough, and to assess the adhesion quality of the starch to the dough. Manthey et al. (2006) used Mixolab to evaluate the rheological and gelatinization properties of durum wheat grown in the USA [7]. Mixolab instrument is generally used to characterize the rheological behavior of the dough which subjected to simultaneous mixing and temperature limitation. The torque $(\mathrm{Nm})$ produced by mixing the dough between the kneading arms is a parameter measured in real-time [8]. Some of the studies carried out with the help of Miksolab for the evaluation of pasta production quality of various wheat kinds [7] estimation of the suitability of flour for cake quality [9] and hydrocolloids [10] and flaxseed [11] investigation of the effect of flour dough rheological properties. The five parameters $(\mathrm{C} 1, \mathrm{C} 2$, C3, C4, C5) generally used to evaluate the Mixolab curve shown in Figure 1. 


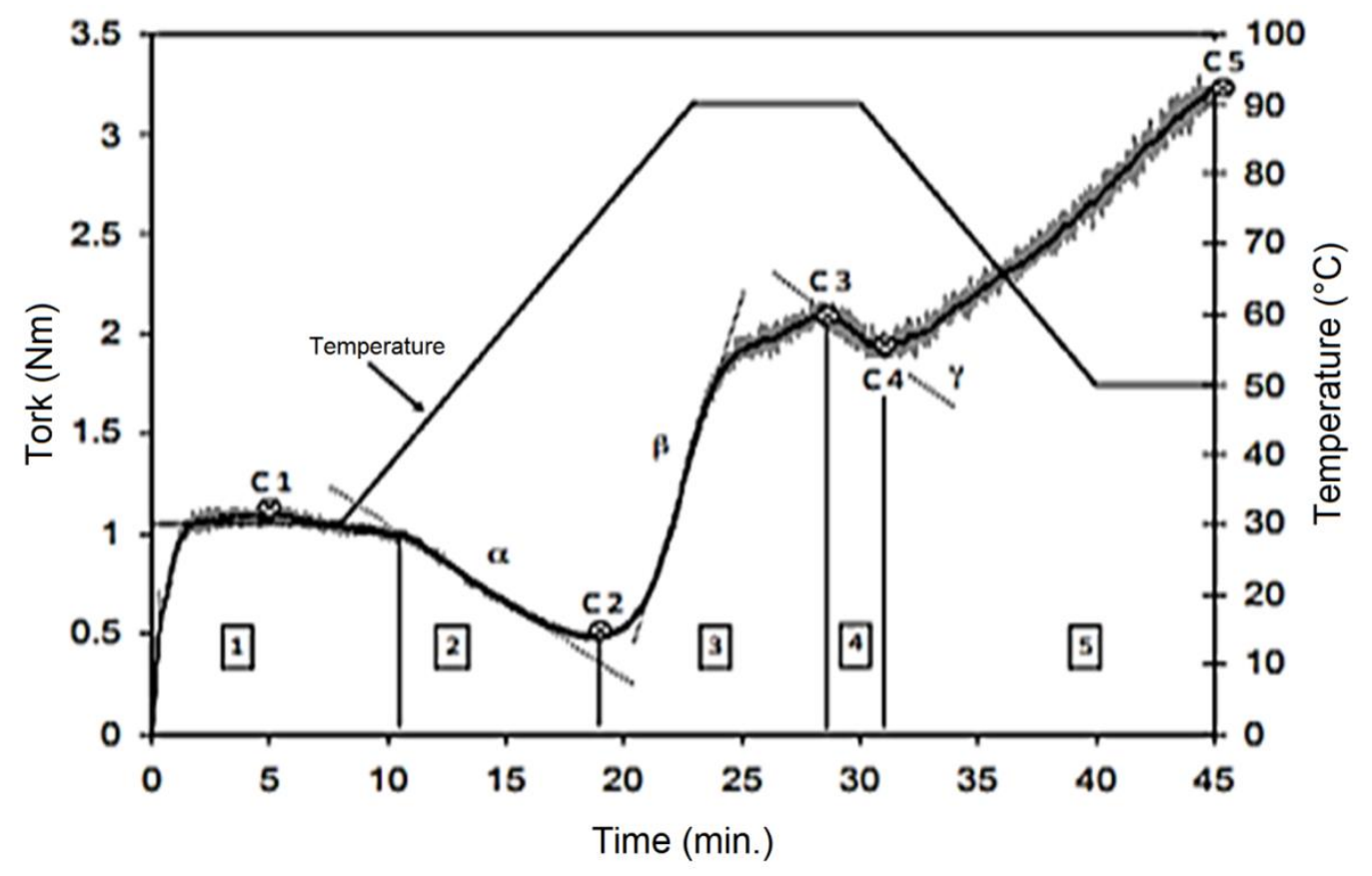

Figure 1. Mixolab five parameters used to evaluate the Mixolab curve (C1, C2, C3, C4, C5).

In step 1, where dough mixing properties such as stability, elasticity, and water absorption determined, an increase in torque observed until the maximum is reached [8]. $\mathrm{C} 1$ represents the maximum point in the first mixing step, such as water absorption, stability, elasticity, and at this stage, the dough's behavior against kneading determined.

In step 2, the consistency of the dough reduced by excessive mixing, this is an indicator of protein weakness. The difference between the start and end of stage 2 is associated with the amount of gluten. In step 3 , with the increase in temperature, a decrease is observed first due to starch gelatinization and then an increase in the concentration. In the fourth stage, the consensus decreases as a result of the amylolytic activity. The reduction in stage 4 concentration gives an idea of the stability of the starch gel during heating and is also associated with the amylase activity of flours. In the fifth phase, the decrease in temperature causes an increase in the consensus as a result of gel formation, which is thought to be related to the retrogradation of starch $[8,9,12,13]$. When kneading the samples in Mixolab kneading bowl, the amount of water they take until $1.1 \mathrm{Nm}$ torque calculated as water absorption. In addition to the quality parameters, the glutograph device was widely used in measure of stretch gluten extension and elasticity measurements in recent years [14]. As gluten strength and quality increase, stress $(\mathrm{sec})$ is expected to increase, and relaxation (BU) and stress (BU) values are expected to decrease [15]. Gluten quality value calculated using the obtained stress $(\mathrm{sec})$ value is required to be higher than 5 in durum wheat breeding lines. Ünsal et al. (2009) In their study, intact and sun-damaged condition wheat gluten stress (s) value 
of wet samples and dry and gluten values decreased compared to sound samples, relaxation (BU) value was found to increase compared to intact samples [16].

This study aimed to investigation of rheological properties of wheat flour doughs obtained from 6 wheat genotypes( 3 red, and 3 white bread) bythe farinograph, extensograph, Mixolab and glutograph measurements.

\section{Materials and Methods}

\subsection{Materials}

In this study, used wheats were purchased from Sanliurfa Wheat Exchange and were selected from registered wheat, which has 1st class quality characteristics according to Turkish Standards Institution (TSE 2974) [17]. Wheat samples determined as 3 red bread (Pandas, Sagitorya, Pehlivan) and 3 white bread (Kaşifbey, Göktan, Ceyhan-99). All chemicals and solutions used in the analyses used in analytical purity.

\subsection{Equipments}

The dough development time (DDT), dough stability (DS), degree of softening (DoS), and farinograph quality number (FQN) were determined using a Brabender model 8124 farinograph (Brabender OHG, Germany) according to AACC Method 54-21.

To determine the resistance and extension ability of the doughs to shrink, Method 54-10 used, and the extensograph test determined on the BrabenderExtensograph device.

Gluten "stretch" and "relaxation” values were determined using Brabender Glutograf-E (Duisburg, Germany). Glutograph parameters (stretch and relaxation) were determined, according to Anonymous (2005 [18].

Dough mixing and pasting behaviors of the wheat flour samples were studied using the Mixolab®) (Chopin Technologies Villeneuve La Garenne, France). The rheological mixing characteristics of these wheat flour samples were tested with the Chopin Mixolab Instrument using the standard "Chopin+" protocol and with Brabender-Farinograph using ICC evaluation method.

\subsection{Preparation of flour blends}

A total of 6 wheat samples of red and white wheat bread varieties were first tempering by cold tempering process. The tempering process was carried out in 3 stages. In the first stage, $2 / 3$ of the required water and in the second stage, 1/3 were added and kept at room temperature for 24 hours. After the tempered milled in a 
Brabender Junior roller mill, the flours obtained by passing through number $8(180 \mu)$ sieve were kept in closed containers at $+4{ }^{\circ} \mathrm{C}$ to prevent color change.

\section{Results and Discussion}

\subsection{Flour yields of wheat samples}

A total of 6 wheat samples of red and white wheat bread varieties were first tempering by cold tempering process. The tempering process was carried out in 3 stages. In the first stage, $2 / 3$ of the required water and in the second stage, 1/3 were added and kept at room temperature for 24 hours. After the tempered milled in a Brabender Junior roller mill, the flours obtained by passing through number $8(180 \mu)$ sieve were kept in closed containers at $+4^{\circ} \mathrm{C}$ to prevent color change. Flour yields of each wheat varieties are given Table 1 and Figure 2.

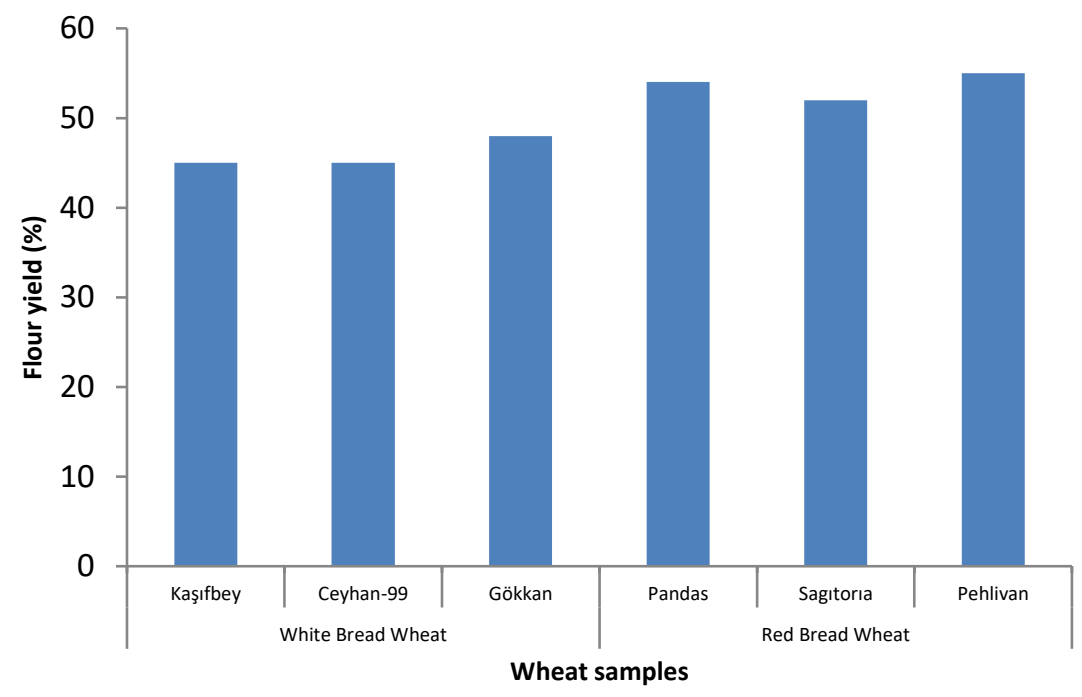

Figure 2. Flour yields of each wheat varieties (red and white).

According to Figure 2 and Table 1, the highest flour yield was generally seen in red bread wheats. The highest yield of red bread wheat varieties was determined as Pehlivan with a rate of 55\%. The flour yields obtained from white bread varieties were almost close and $46 \%$ flour yield was determined on average.The results of research in the literature indicate that there is a difference in the quality and yield levels of the cultivars used according to the region and conditions in which they are grown [19-23]. 
Table 1. Flour yields and flour amount of each wheat varieties.

\begin{tabular}{llccc}
\hline & & Wheat amount (gr) & Flour amount (gr) & Flour yield(\%) \\
\hline \multirow{2}{*}{ White Bread Wheat } & Kaşıfbey & 2000 & 900 & 45 \\
& Ceyhan-99 & 2000 & 900 & 45 \\
& Gökkan & 2000 & 950 & 48 \\
& Pandas & 2000 & 1080 & 54 \\
Red Bread Wheat & Sagitoria & 2000 & 1050 & 52 \\
& Pehlivan & 2000 & 1100 & 55 \\
\hline
\end{tabular}

\subsection{Rheological properties of dough samples}

\subsubsection{Farinograph analysis}

The obtained data from the Farinograph analysis are used to determine the amount of water required for flour to form dough at a certain concentration and to determine the resistance of the dough to the kneader during kneading and the development of gluten in the dough.Figure 3 shows the farinograph data of doughs from flours of white and red bread wheat varieties. Water absorption properties, defined as the amount of water required achieving optimum dough consistency, refers to the amount of liquid required to obtain the best final product with dough with good kneading and processing properties. It is desirable to have high water removal, which is an important quality criterion in bread production [5]. 

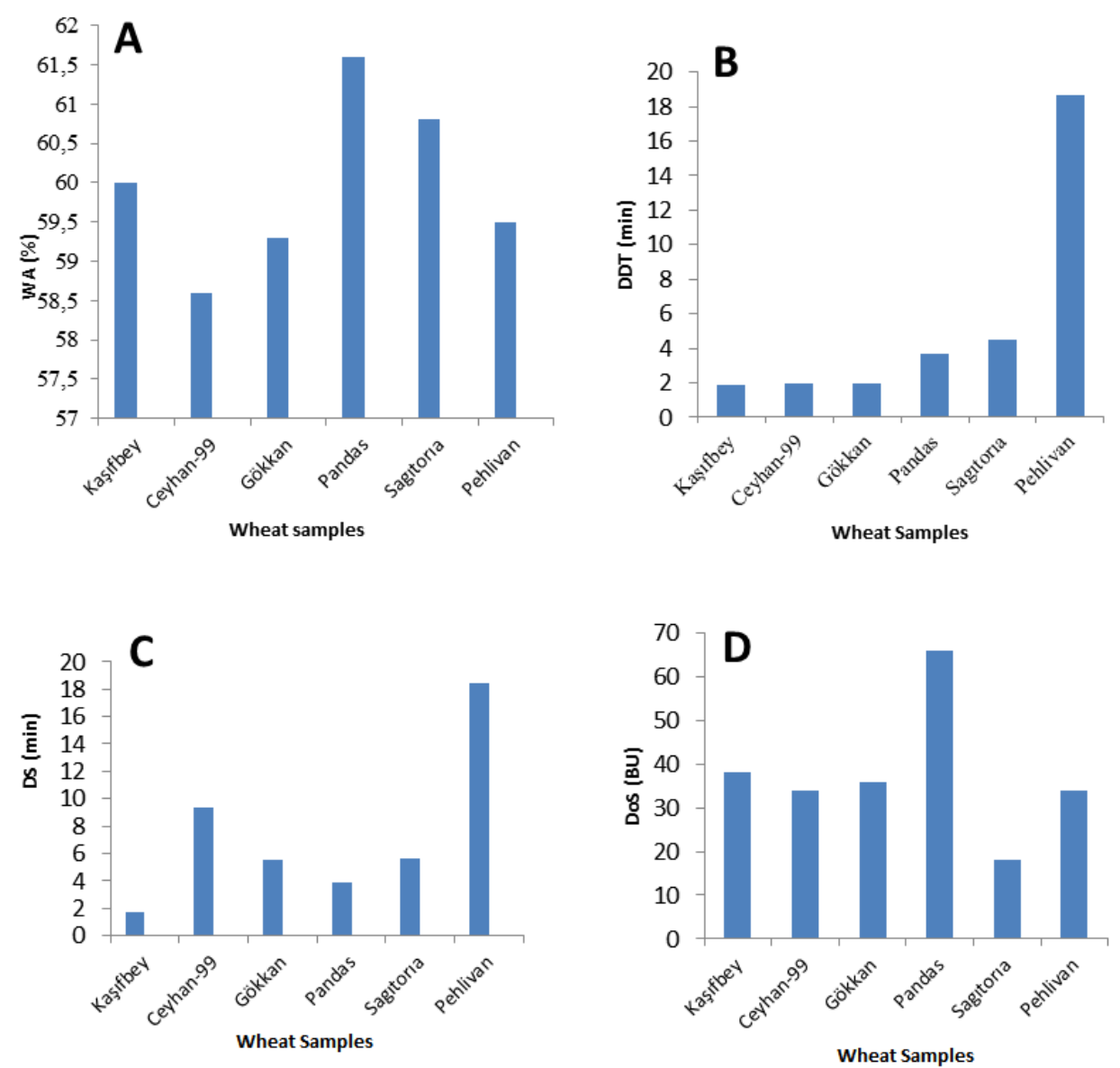

Figure 3. Farinograph data of flours of white and red bread wheat varieties. (A) WA, Water absorption (\%), (B) DDT, dough development time, (C) DS, dough stability, (D) DoS, degree of softening.

In this study, the average of water absorption of white bread varieties of the common wheat genotypes farinograph average of $59.3 \%$, the average value of water absorption of red bread varieties were determined as 60.63\%. The highest water absorption rate was obtained from Pandas with $61.60 \%$ and Ceyhan-99 genotypes with $58.60 \%$ (Figure 3A). Kitterman and Rubenthaler (1971), which has a water removal rate of less than $60 \%$ of the soft wheat flour, over $60 \%$ of them defined as hard wheat flour [24]. Aydoğan et al. (2013) in their study of the different types of bread wheat genotypes, the highest water absorption of $62.10 \%$, the lowest $56.40 \%$ of the average, found to be $59.85 \%$.Dough development time is a measure of gluten strength and increases as protein content increases [1]. The length of the development time, the length of the kneading time and the quantity and quality of the core indicate the high [25]. Bread quality of flour with short kneading time is generally low. In this study, the average duration of development of white bread genotypes was 1.95 minute. The average duration of development of red bread genotypes was determined as 8.96 min. The highest development time with 18.70 Pehlivan, the lowest development time was determined in 1.90 minutes as Kaşifbey varieties (Figure 3 B). Dogan and Ugur (2005), in a study conducted in the Van region in 10 wheat 
varieties have found that the time between the development of the farinograph (1.8 to 4 min.). In a study, the development time of different wheat genotypes 2.15 to $4.25 \mathrm{~min}$ [26]. Stability of dough is a parameter that indicates the dough's resistance to processing. Short stability results in shortening of the dough's ability to process and fermentation time. When we examine the stability value of bread wheat genotypes, the average white bread variety is $5.55 \mathrm{~min}$. The average stability values of red bread wheat variety determined as $9.3 \mathrm{~min}$. Pehlivan with the highest stability value was found to be 18.40 minutes, and Kaşifbey with the lowest stability value was determined to be 1.70 minutes (Figure 3.C). Stability values and development times are parallel with each other. Dogan and Ugur (2005) reported that the stability of the farinograph ranged from 2.3 to 10 minutes [26]. Increased of softening degree in the Farinograph is associated with poor gluten quality.In the study, the average softening degree of white bread varieties determined as $36(\mathrm{BU})$ and the average softening degree of red bread varieties as 39.3 (BU). Dogan and Ugur (2005) reported that the stability of the farinograph ranged from 2.3 to 10 minutes [26].

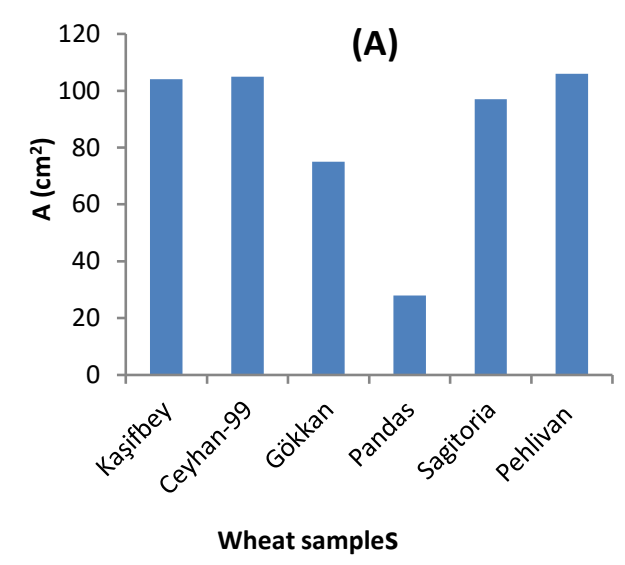

(B)

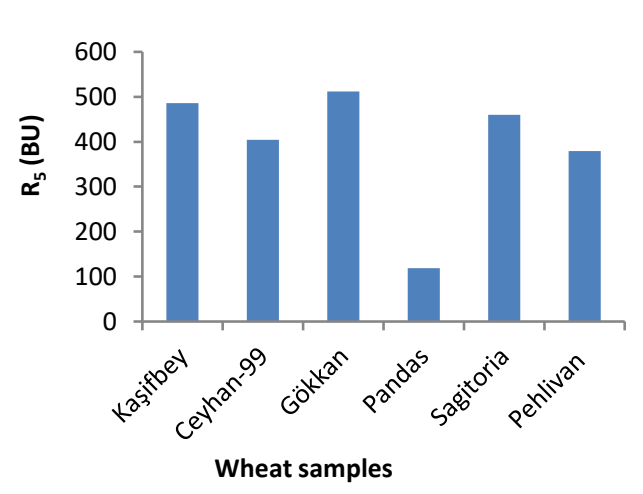

(D)

(C)
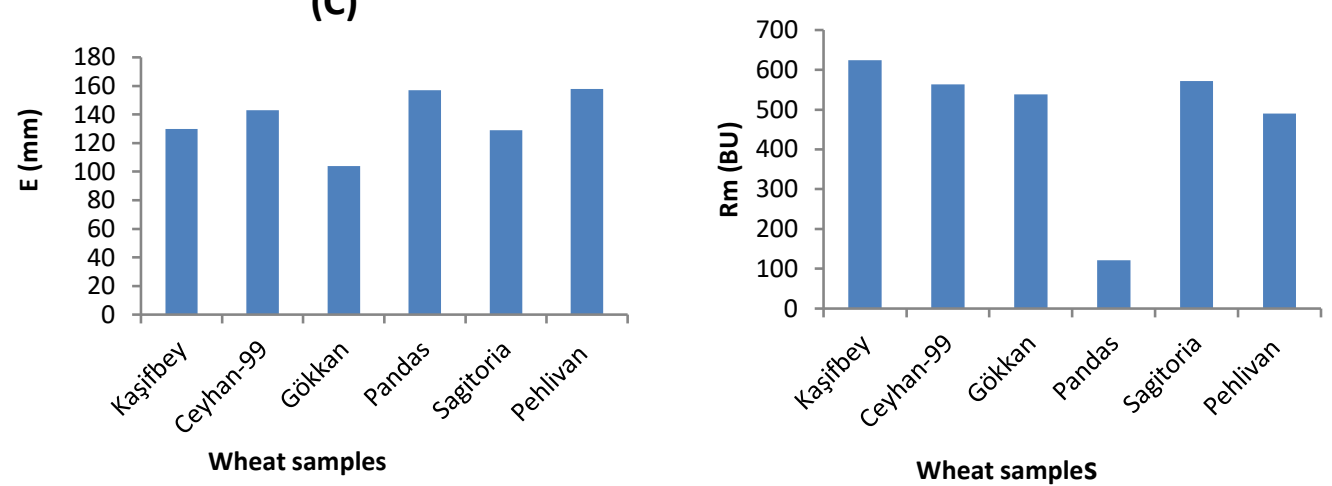
(E)

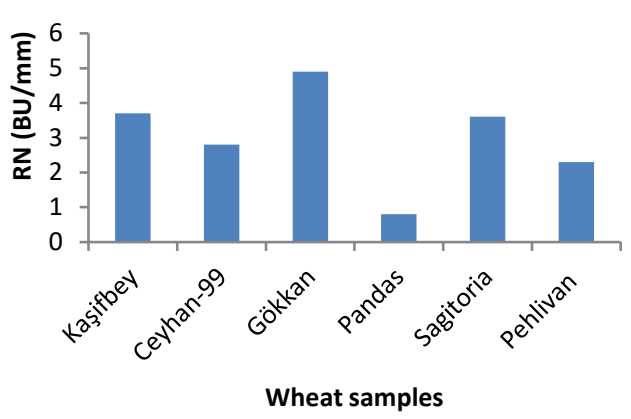

Figure 4. The results of extensograph analysis of white and red bread wheat flour. (A)A, Energy $\left(\mathrm{cm}^{2}\right)$; (B) R5, Dough resistance to elongation (BU); (C) E Extensibility (mm ); (D) Rm, maximum elongation of the dough against elongation (BU); (E) Ratio number (BU/mm).

\subsubsection{Extensograph analysis}

The extensograph device was used to determine the resistance and extension ability of the dough obtained from different wheat varieties. For this purpose, Mill flour milled flour using the combined dough tester values extensogram values (Rm: maximum extension of the dough against extension (BU), R5: Dough resistance to extension (BU), E: Extensibility $(\mathrm{mm})$ and A: Energy $\left(\mathrm{cm}^{2}\right)$ ). Laboratory studies performed in 3 replications. Figure 4 shows the results of extensograph analysis of white and red flour of bread wheat.To reveal the rheological properties of wheat flour, extensograph parameters investigated in different studies. [23, 26-27]. The energy value is an essential parameter in terms of the dough's resistance to processing and the degree of workability. The higher this value, the greater the gas holding capacity and fermentation tolerance of the dough.According to the table data, although the energy value determined in the highest Pehlivan (RBW) cultivar with 106 , it is generally found that white bread varieties have higher values than red bread varieties.It stated that the energy value of the flour obtained from bread wheat should be higher than $80 \mathrm{~cm}^{2}$ and thus the gas holding capacity and fermentation tolerance of the dough would be high [25]. It was reported by Başaran and Göçmen (2003) that energy value gives information about the properties of bread.It is seen that energy values are higher than $80 \mathrm{~cm}^{2}$ in other varieties except for Pandas and Gökkan varieties [28]. The extension resistance (R5) (BU) and extensibility $(\mathrm{mm})$ of the dough are the parameters used to determine the processability of wheat to different products and the baking properties of flour [1]. The ability of the dough to hold the $\mathrm{CO}_{2}$ gas produced during fermentation is related to its ability to grow and its extension resistance. When, the dough has high extension resistance, the volume of bread increases [3]. White bread varieties showed high extension resistance than red 
bread varieties. The kind of red bread wheat, which shows the lowest elongation resistance determined as Pandas with the BU value of 119. Gökkan variety with 512 (BU) showed the highest extension resistance. According to Figure 4, it is possible to say that the flour varieties obtained from white bread kinds of wheat have superior baking properties compared to red wheat flour. The extensibility (mm) value is the base length of the curve and expressed in $\mathrm{mm}$. It refers to the time from the moment the dough starts to pull until it breaks. It is the parameter related to the elasticity of the dough. The high extensibility value show the better the gas holding capacity and fermentation tolerances of the dough. Dough with high extensibility value gives more bulky bread [3]. According to the Figure 4, extensibility values vary between $104 \mathrm{~mm}$ and $158 \mathrm{~mm}$ and extensibility values of red bread varieties are higher than white bread varieties. The highest extensibility value found in Pehlivan sample with $158(\mathrm{~mm})$ value, and the lowest value found in Gökkan sample with $104(\mathrm{~mm})$ value. In a study, the determined extensibility of wheat flour dough was measured as $146.7 \mathrm{~mm}$ [29]. In another study, it reported that the extensibility values of different wheat flours determined by the extensograph device varied between 146-208 mm [30]. Extensibility value ( $\mathrm{mm})$ was higher in red bread wheat varieties than white bread varieties. In this study, the maximum extensibility $(\mathrm{Rm})$ value was found higher in white bread varieties. The maximum extensibility $(\mathrm{Rm})$ value belongs to Kaşifbey variety with 624 (BU). Maximum extensibility (BU) is reported to be significantly affected by the protein content of flour. In many studies, it stated that the extensibility value increases with increasing protein content [31-33].

In general, it found that the resistance of the dough to extension (R5), the maximum resistance of the dough to extension ( $\mathrm{Rm})$, the energy (A) expressing the curved area and the ratio value were higher in white bread wheat varieties. The extensibility $(\mathrm{mm})$ value was higher in red bread wheat varieties than white bread varieties. The extensibility $(\mathrm{mm})$ value is related to the elasticity of the dough.

\subsubsection{Mixolab analysis}

Mixolab device is a device that determines the rheological properties and changes of the dough by increasing or decreasing the temperature values of the flour during dough formation [34]. There are many studies using mixolab in determining rheological properties of bread dough $[9,35,36]$. Mixolab results provide a wealth of information on dough baking properties, flour compositions, ingredients or similar [37-40] Table 2 shows the mixolab values of the doughs of wheat varieties. 
Table 2. Mixolab values of doughs of wheat varieties Water ab .: Water absorption (\%), C1: Torque (Nm), Stblt: (stability) (min) C2: Torque (Nm), C3: Torque (Nm) C4: Torque (Nm) C5: Torque (Nm), $\alpha$ : Alpha angle, $\beta$ : Beta angle, y: Gamma angle.

\begin{tabular}{|c|c|c|c|c|c|c|c|c|c|c|c|c|}
\hline & & Variery & $\begin{array}{c}\text { Water } \\
\text { abs. }\end{array}$ & $\mathrm{C} 1$ & Stablt & $\mathrm{C} 2$ & $\mathrm{C} 3$ & $\mathrm{C} 4$ & $\mathrm{C} 5$ & $\alpha$ & $\beta$ & $\mathrm{y}$ \\
\hline \multirow{3}{*}{ 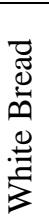 } & \multirow{3}{*}{$\begin{array}{l}\vec{\Xi} \\
\frac{\vec{J}}{3}\end{array}$} & Kaşifbey & 68.7 & 1.144 & 1.15 & 0.662 & 1.611 & 1.450 & 2.029 & 0.062 & 0.158 & 0.008 \\
\hline & & Ceyhan-99 & 66.4 & 1.093 & 7.47 & 0.590 & 1.609 & 1.487 & 2.342 & 0.068 & 0.312 & 0.042 \\
\hline & & Gökkan & 69.6 & 1.153 & 4.75 & 0.585 & 1.461 & 1.344 & 1.917 & 0.062 & 0.178 & 0.008 \\
\hline \multirow{3}{*}{ 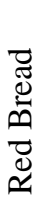 } & \multirow{3}{*}{$\sum_{\vec{\Xi}}^{\vec{E}}$} & Pandas & 68.4 & 1.107 & 4.53 & 0.582 & 1.670 & 1.580 & 2.408 & 0.064 & 0.302 & 0.040 \\
\hline & & Sagitoria & 66.4 & 1.132 & 6.53 & 0.621 & 1.832 & 1.609 & 2.349 & 0.090 & 0.492 & 0.064 \\
\hline & & Pehlivan & 68.2 & 1.119 & 4.53 & 0.571 & 1.583 & 1.508 & 2.661 & 0.072 & 0.300 & 0.008 \\
\hline
\end{tabular}

The Mixolab device used to evaluate the effects of different protein sources on wheat dough functionality by Bonet et al. (2006) [41]. Rosell et al. (2007) determined the molecular structure of different hydrocolloids on dough obtained from wheat flour using mixolab device [42]. The use of different flours in the baking quality of cookies was carried out with a mixer device [8]. A study on the use of different wheat genotypes in bread production with mixolab application [12]. Also, the effect of dietary fibers on pulp [10], The relationship between different flour sources' performance and quality parameters [43] are some of the studies performed with Mixolab device. In the initial mixing stage of the mixolab, homogeneous, viscoelastic dough formation occurs due to the interaction between flour and water molecules. $\mathrm{C} 1$ is a parameter that shows the maximum point of the first mixing step and the behavior of the dough against kneading. When evaluating the $\mathrm{C} 1 \mathrm{region}$, it is healthier to evaluate with stability. Among the cultivars, $\mathrm{C} 1$ value of white bread varieties was found to be highest. In step 2, the consistency of the dough decreases with excessive stirring, and the mixolab curve shows a downward slope. In this region, $\mathrm{C} 2$ torque value determined as white bread variety average 0.612 , red bread variety average was 0.591 , and C2 values of genotypes were found to be between 0.571 and $0.662 \mathrm{Nm}$. The difference between the beginning and the end of the $\mathrm{C} 2$ phase is associated with the amount of gluten. The values of white bread wheat dough in the $\mathrm{C} 2$ region were found to be higher than those obtained from red bread wheat dough. In the $\mathrm{C} 2$ region where the temperature rises, denaturation of proteins begins, and the resistance of the protein to kneading decreases. White bread wheat varieties show more resistance than red bread varieties in this region. The difference between $\mathrm{C} 2$ and $\mathrm{C} 1$ gives information about protein quality. When the relation 
between $\mathrm{C} 2$ torque and other properties examined, it found that there was a negative relationship with protein ratio. The starch gelatinizes due to the increased $\left(90^{\circ} \mathrm{C}\right)$ temperature in the $\mathrm{C} 3$ region and the resistance of the dough to kneading increases. The steep slope of the graph may be desirable in bread assessments. Reducing the consistence from $\mathrm{C} 3$ to $\mathrm{C} 4$ gives an idea of the stability of the starch gel during heating and is also associated with the amylase activity of the flour. C3tork value was found to be 1.56 for white bread varieties, 1.69 for red bread varieties. While Gökkan variety has the lowest value, Sagitorya (RBW) variety has the highest value. In the $\mathrm{C} 4$ zone, the temperature is kept constant at $90^{\circ} \mathrm{C}$. Here, the reduction of the consensus from $\mathrm{C} 3$ to $\mathrm{C} 4$ gives an idea of the stability of the starch gel during heating. It is associated with the amylase activity of flour and provides information about the level of amylase enzyme. In this study, the highest $\mathrm{C} 4$ torque values found in Sagitoria with $1.609 \mathrm{Nm}$ and the lowest in genotypes with Gökhan with $1.344 \mathrm{Nm}$.

The decrease in temperature in section $\mathrm{C} 5$ (from $90^{\circ} \mathrm{C}$ to $50^{\circ} \mathrm{C}$ ) is associated with retrogradation of starch with the cooling of the dough $[8,9,12,13]$. In this case, when the starch molecules are cooled, the water molecules go into the Free State, the resistance of the dough to the kneading arms increases and the starch hardens. The C5 value should be low in that the bread is stale later. In this study, the highest $\mathrm{C} 5$ torque value measured in Pehlivan cultivar with $2.661 \mathrm{Nm}$. The lowest C5 torque value determined in Gökkan variety with $1.917 \mathrm{Nm}$. Szafranska (2010) in their work the lowest value of C5 torque $1.42 \mathrm{Nm}$, the highest value was $3.26 \mathrm{Nm}$. C5 value was $2.09 \mathrm{Nm}$ for white bread variety and $2.47 \mathrm{Nm}$ for red bread variety [44]. Water absorption is the amount of water that the samples take up to $1.1 \mathrm{Nm}$ torque when kneading and the dough should reach a torque of $1.1 \mathrm{Nm}$ in the $\mathrm{C} 1$ region for a long time in terms of the stability and stability of the dough. This time should be extended. In genotypes with strong protein structure, this time is expected to belong.
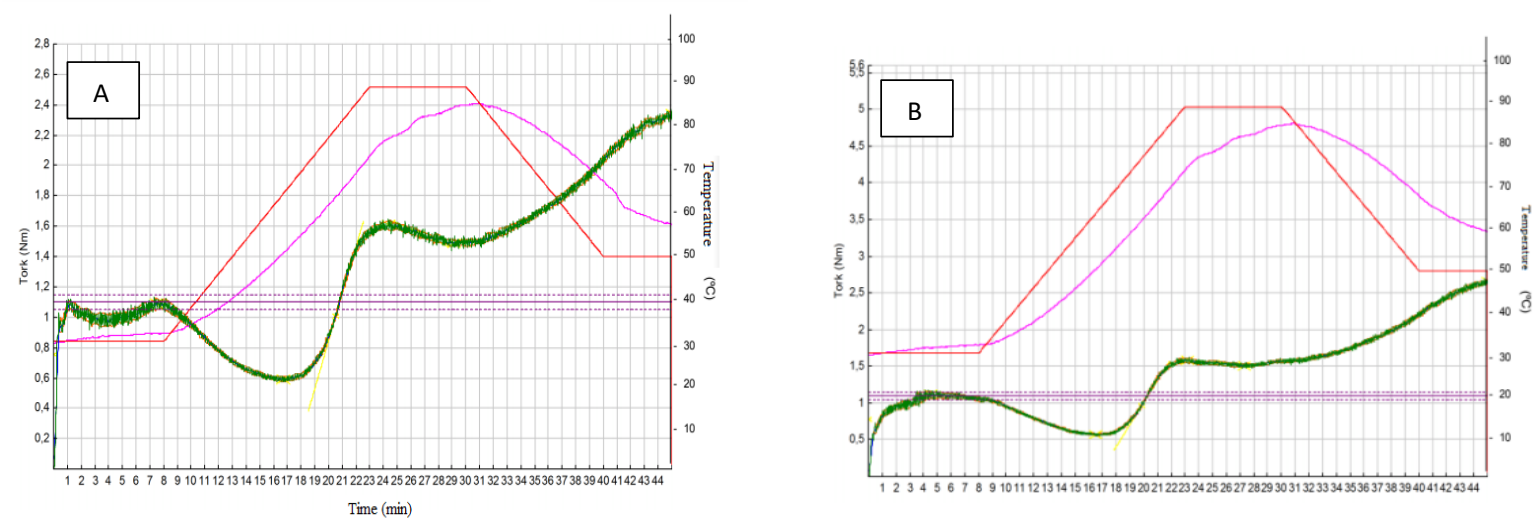

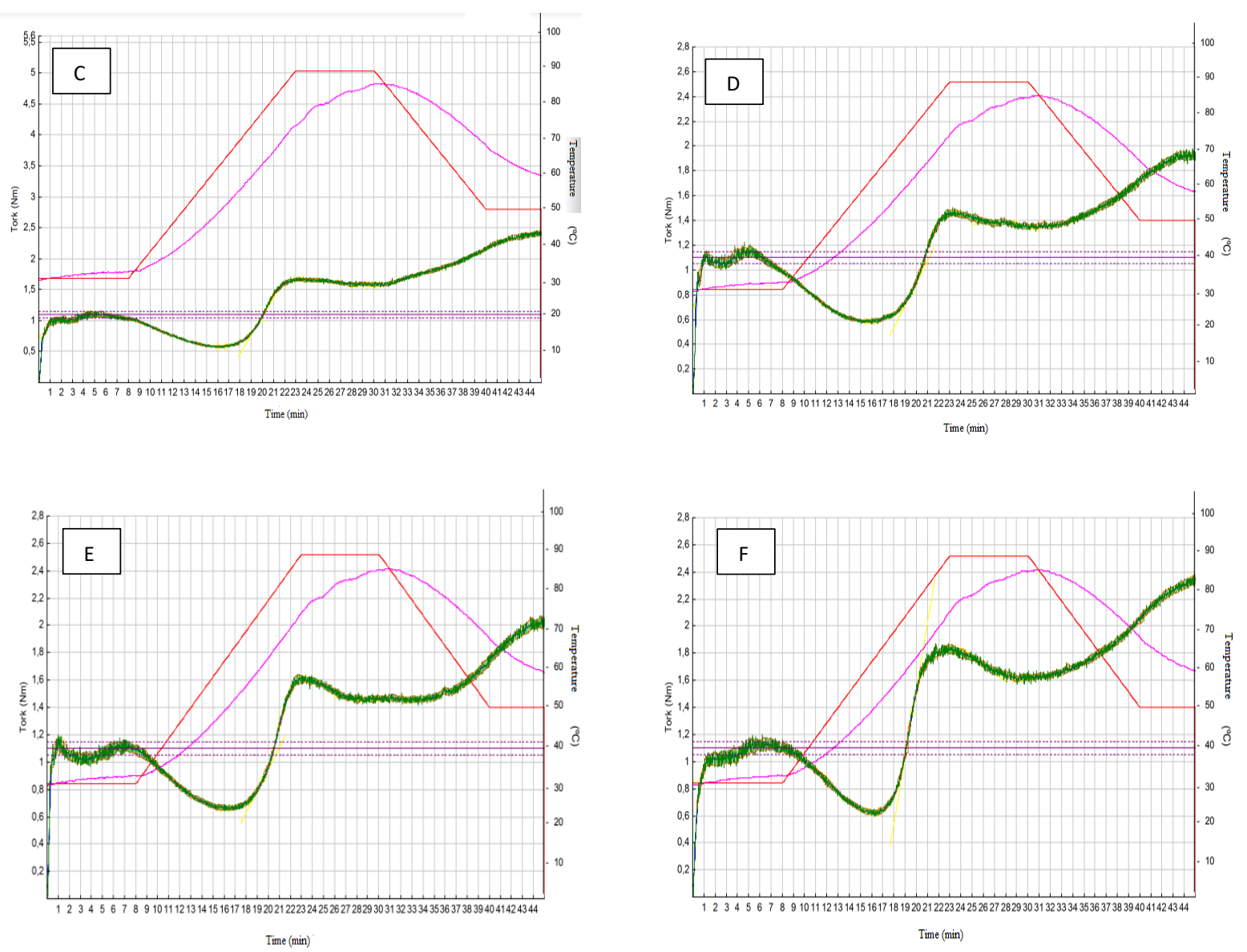

Figure 5. Mixolab image of wheat varieties. (A) Ceyhan-99 ,(B) Pehlivan, (C) Pandas, (D) Gökkan, (E) Kasifbey, (F)Sekuterya

Three different angle values $(\alpha, \beta, \gamma)$ were indicated on the mixolab graph in Figure 5. The average $\alpha$ angle of white bread wheat varieties was 0.06 , and that of red bread varieties was 0.07 . The angle $\alpha$ is called the steeper, the weaker the gluten, the narrower, the stronger the gluten. The values of the two varieties were determined to be very close to each other. The $\beta$ angle was 0.21 for white bread wheat varieties and 0.36 for red bread varieties. The $\beta$ angle, the more perpendicular the dough, the lower the viscosity of the dough is hard, and vice versa, the dough is called softer fluid. According to these data, the dough obtained from red bread wheat varieties is harder. When evaluated in terms of y angle; while the average angle of white bread varieties was 0.01 , it was determined as 0.03 in the samples obtained from red bread wheat varieties. The angle y indicates the effect of the amylase enzyme .Mixolab application also provides information about profile values and graphs of the samples. It gives figures ranging from 1 to 9 about water absorption, kneading performance, gluten strength, amylase activity, and starch retrogradation of the varieties and forms a profile graph with these figures (Figure 6). 


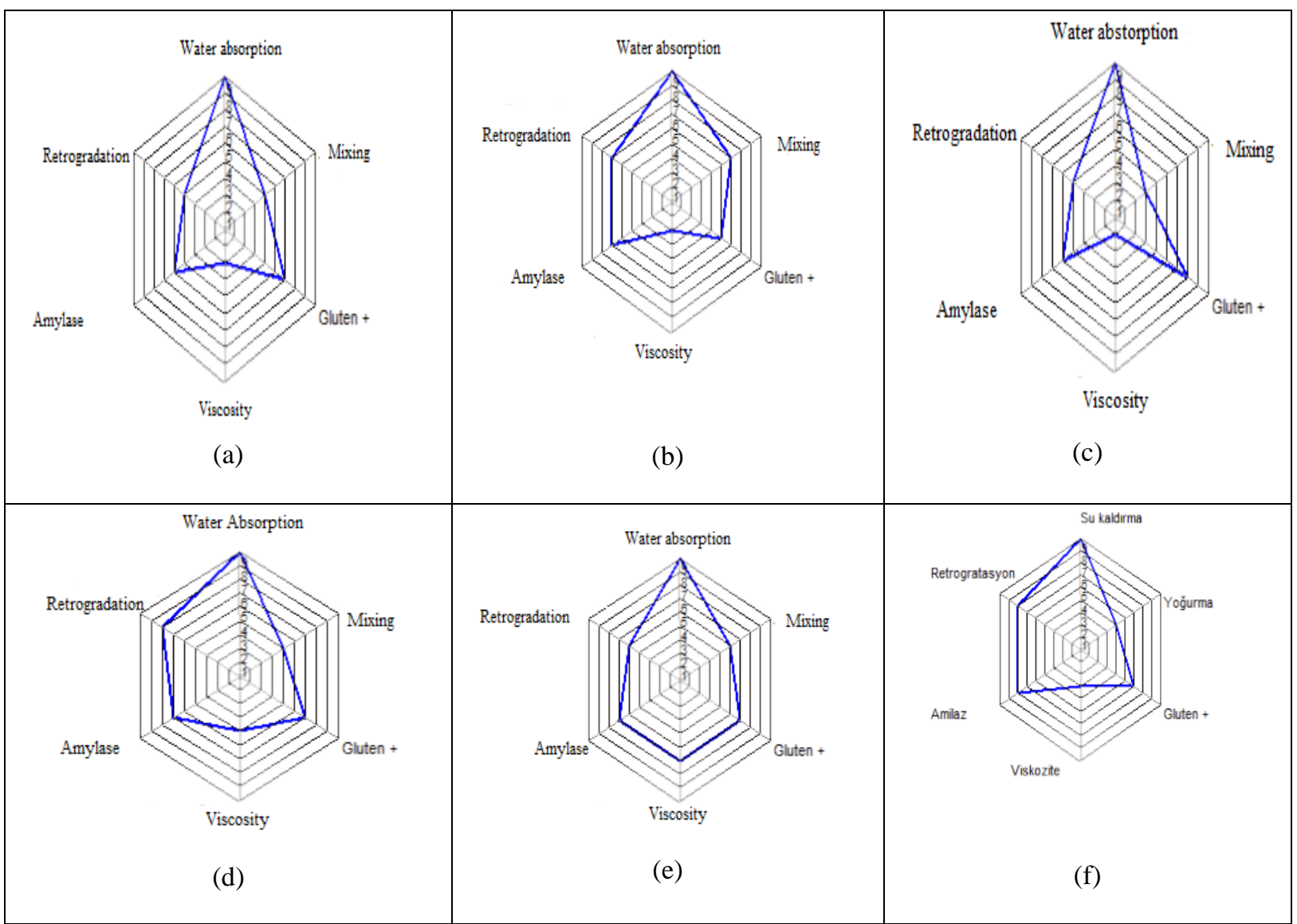

Figure 6. Profile images of wheat varieties. (a) Kasifbey, (b) Ceyhan-99, (c) Gökkan, (d) Pandas, (e) Sekuterya, (f) Pehlivan

Table 3. Mixolab profile values of white and red bread wheat varieties WA; WaterAbsorption, Mix; Mixing, Glt: Gluten, Vis; Viscosity Aml: Amylase, Ret: Retrogradation

\begin{tabular}{llllllll}
\hline & Variety & WA & Mix. & Glt & Vis & Aml & Ret \\
\hline White & Kaşifbey & 9 & 4 & 6 & 2 & 5 & 4 \\
Bread & Ceyhan-99 & 9 & 6 & 5 & 2 & 6 & 6 \\
Wheat & Gökkan & 9 & 3 & 7 & 1 & 5 & 4 \\
\hline Red & Pandas & 9 & 4 & 6 & 4 & 6 & 7 \\
Bread & Sagitoria & 9 & 5 & 6 & 6 & 6 & 7 \\
Wheat & Pehlivan & 9 & 4 & 6 & 3 & 7 & 7 \\
\hline
\end{tabular}

It provides ease of visual evaluation in the evaluation of sample profiles previously analyzed with profile graphs. In this study, all varieties had the highest value in terms of water removal capacity from profile values. Ceyhan99 varieties in terms of kneading properties, Gökkan varieties in terms of gluten properties, Sagitoria varieties in 
terms of viscosity value, Pehlivan varieties in terms of amylase value, Pehlivan and Pandas in terms of starch retrogradation varieties were found to have the highest value.

\subsubsection{Glutograph analysis}

Extension and elasticity of the flours of red and white bread wheat varieties determined with the Brabender Glutograph-E (Brabender, Duisburg, Germany). As gluten strength and quality increase, stretch (sec) value is expected to increase, relaxion (BU) and stretch (BU) value are expected to decrease [18]. Glutograph values of wheat flour used as in Figure 7.

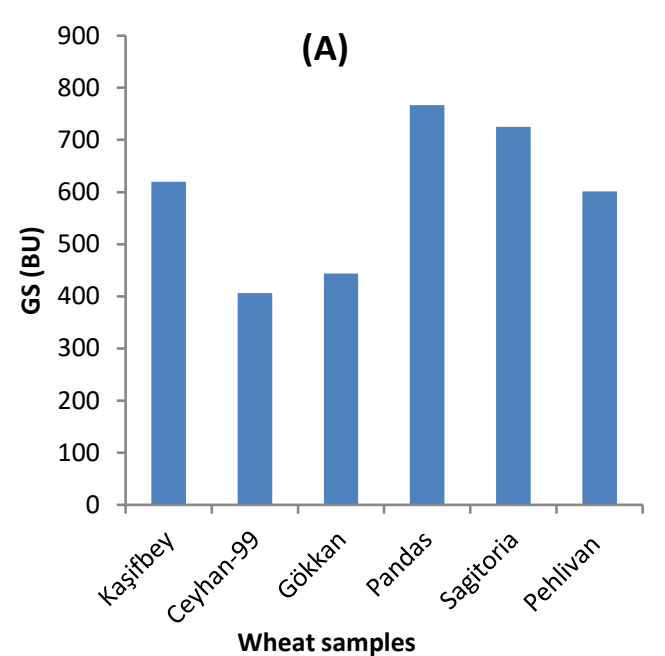

(C)

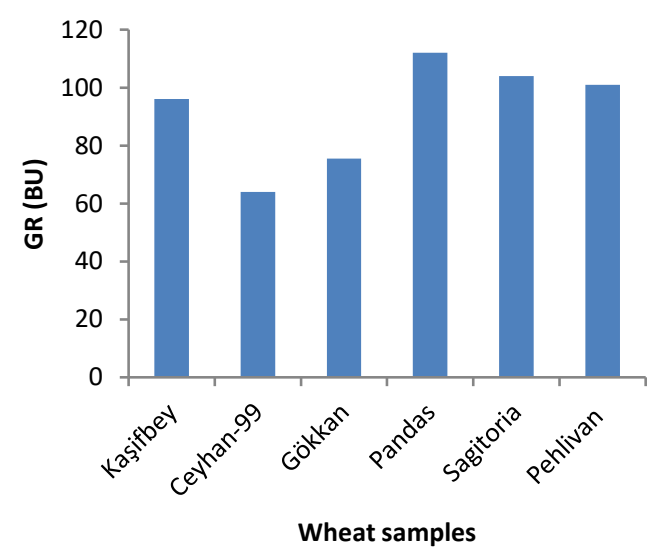

(B)

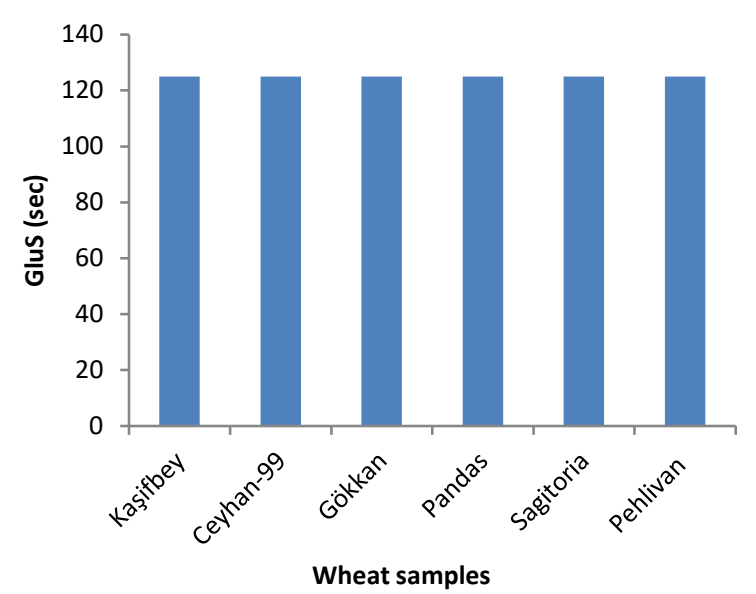

(D)

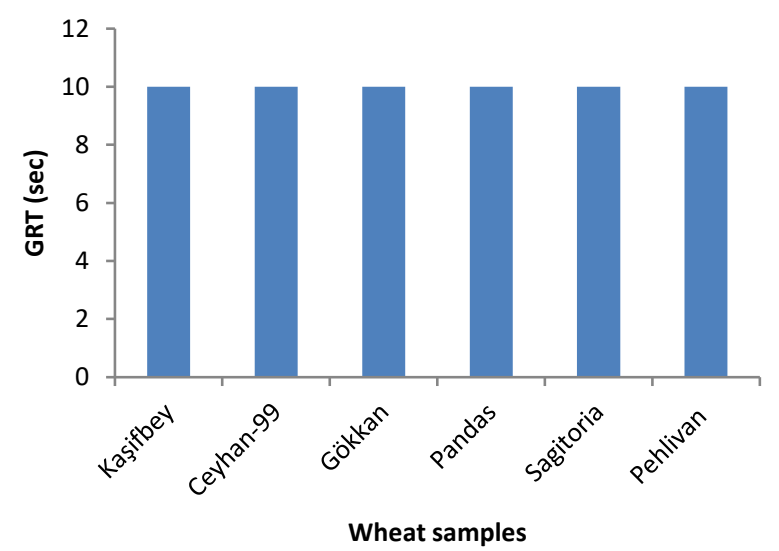

Figure 7. Glutograph values of wheat flours. (A) GS, Glutograph stretch (BU), (B) GluS, Glutographstrech (sec), (C) GR, Glutograph relaxation (BU), (D) GRT, Glutograph Relaxation Time (sec)

Glutograph is a device that expresses the resistance of wheat protein gluten to stretch time in seconds (sec) [14] .

Generally, flour with a strong gluten structure has a high value of seconds. In the glutograph analysis, stretch 
(extension) is the measure of the elongation of gluten and relaxation (stretching) is the measure of elasticity.As the gluten strength and quality of flour increased, it is expected to increase in stress $(\mathrm{sec})$, decrease in relaxation (BU) and strain (BU) [18]. According to the Figure 7, the wheat with the highest stretch value (BU) is the red bread wheat group. Stretch the value of Pandas varieties in this group determined as 767 (BU). Stretching value of white bread wheat was found to be less than that of red bread wheat. The evaluation in terms of elongation value is in parallel with the stretch values. The highest elongation value determined as 112 (BU) value for Pandas varieties, which is a red bread variety. Glutograph extension time determined as 10 seconds for all cultivars. Glutograph stretch (BU) or relaxation values range from 406 to 767 (BU).

In a study investigating the quality criteria of some bread genotypes, found that the elongation (s) values ranged from 9-125 s to $80 \mathrm{~s}$, the relaxation (BU) values ranged from 198-715 BU and the average was 557.7 BU [46]. Based on this information, it concluded that white bread wheat varieties are more suitable for bread production.

\section{Conclusion}

In this study; rheological properties of flour dough obtained from white and red bread wheat varieties were measured using farinograph, extensograph, mixolab and glutograph devices and relationships between varieties were determined. In extensograph application, it determined that white bread varieties had higher gas holding capacity, and dough showed more resistance to elongation. The extensibility value associated with the elasticity of the dough was higher in red bread wheat varieties. Mixolab is a device that determines the rheological properties of the dough during the dough formation and changes in temperature. In this study, kneading properties of Ceyhan-99 varieties, gluten propeties of Gokkan varieties, viscosity value of Sagitoria varieties, amylase values of Pehlivan varieties, starch retrogradation of Pehlivan and Pandas varieties were high.

According to the result of Glutograph measurement, the stretch time was determined as 125 seconds in all cultivars. As gluten strength and quality increase, stretch (sec) value is expected to increase and stretch (BU), and strain (BU) values are expected to decrease. Stretch (BU) and strain (BU) values of white bread wheat varieties were lower than those of red bread wheat varieties.

It concluded that the use of the parameters of these four analyzes in determining the quality of the dough was prominent in the evaluation of bread wheat varieties. 


\section{Acknowledge}

The analyses of farinograph and extensograph in this study were carried out in the Diyarbakır Trade Exchange laboratory.

\section{References}

1. Aydoğan, S.; Göçmen Akçacık, A.; Şahin, M.; Önmez, H.; Demir ,B.; Yakışır, E. Ekmeklik buğday çeşitlerinde fizikokimyasal ve reolojik özelliklerin belirlenmesi. Tarbit Derg. 2013, 22, 74-85.

2. Meral, R.; Yıldız, O.; Doğan, İ.S. Unların reolojik özelliklerinin belirlenmesinde tekstür analiz cihazının kullanımı ve sonuçların ekstensograf değerleri ile karşılaştırılması. Gıda Tekn. Elekt. Der. 2010, 5, 17-24.

3. Hruskova, M.; Smejda, P. (2003). Wheat flour dough alveograph characteristics predicted by NIR systems 6500. Czech J Food Sci. 2003, 21, 28-33.

4. Bloksma, A.H.; Bushuk, W. (1988). Rheology and chemistry of dough. In:Pomeranz Y (ed) Wheat, 3rd edn. American Association of Cereal Chemists, St Paul, 1988, 131-217.

5. Aydoğan, S.; Şahin, M.; Göçmen Akçacık, A.; Hamzaoğlu, S.; Taner S. Relationships between farinograph parameters and bread volume, physicochemical traits in bread wheat flours. Journal of Bahri Dagdas Crop Res. 2015, 3, 14-18,

6. Anderssen, R.S.; Bekes, F.; Gras, P.W.; Nikolov, A.; Wood, J.T. Wheat-flour dough extensibility as a discriminator for wheat varieties. J Cereal Sci. 2004, 39, 195-203.

7. Manthey, F.; Tulbek, M.C.; Sorenson, B. AACC annual meeting: World grain summit: foods and beverages. San Francisco, CA., 2006, 336.

8. Ozturk, S.; Kahraman, K.; Tiftik, B.; Koksel, H. Predicting the cookie quality of flours by using Mixolab (R). Eur Food Res Techn. 2008, 227, 1549-1554.

9. Kahraman, K.; Sakiyan, O.; Ozturk, S.; Koksel, H.; Sumnu, G.; Dubat, A. Utilization of Mixolab (R) to predict the suitability of flours in terms of cake quality. Eur Food Res Technol. 2008, 227, 565-570.

10. Rosell, C.; Santos, E.; Collar, C. Physical characterization of fiber-enriched bread doughs by dual mixing and temperature constraint using the Mixolab®. Eur Food Res Technol. 2010, 231, 535-544.

11. Tulbek, M.C.; Hall, C. AACC annual meeting: World Grain Summit: foods and beverages, San Francisco, 2006

12. Potential utilization of Mixolab for quality evaluation of bread wheat genotypes. Cereal Chem. 2009, 86, $522-526$

13. Dubat, A. A new AACC International approved method to measure rheological properties of a dough sample. CFW Cereal Foods World. 2010, 55, 150-153. 
14. Alamri, M.; Manthey, F.; Mergoum, M.; Elias, E.; Khan, K. The effects of reconstituted semolina fractions on pasta processing and quality parameters and relationship to glutograph parameyters. J Food Techn. 2010, 8, $159-168$

15. Kılıç, H.; Aktaş, H.; Kendal, E.; Altıkat, A.; Karahan, T.; Karaca, V.; Mutlu, Ç.; Duman, M. Farklı fenolojik özelliklere sahip durum buğday genotiplerinin süne (Eurygaster integriceps Put ) zararına mukavemet bakımından değerlendirilmesi. DUFED-Dicle Üniv Fen Bil Ens Der. 2018, 7, 11-12.

16. Ünsal Özderen, N.T. Süne (Eurygaster spp.) zararının makarnalık buğday ve makarna kalitesi üzerine etkileri. Hacetepe University Science Institute / Department of Food Engineering Ph.D. Thesis, 2009, 83.

National thesis no. 244951.

17. Turkish Standards Institution (TSE 2974).

18.Anonymous 2005. Instruction Manual Glutograph-E, Brabender Measurement and Control Systems. Brabender Gmb H \& Co .KG. Kulturstr. 47055 Duisburg, Germany, 2005, 51-55.

19. Altınbaş, M.; Tosun, M.; Yüce, S.; Konak, C.; Köse, E.; Can, R.A. Ekmeklik buğdayda (T. aestivum L.) tane verimi ve bazı kalite özellikleri üzerinde genotip lokasyon etkileri. Ege Üniv Ziraat Fak Der. 2004, 41, 65-74.

20. Tayyar, S. Determination of yield and some quality characteristics of different bread wheat (Triticum aestivum L.) varieties and lines grown in Biga. Akdeniz Univ. J Fac Agr. 2005, 18, 405-409.

21. Aydın, N.; Bayramoğlu, H.O.; Mut, Z.; Özcan, H.. Ekmeklik buğday (Triticum aestivum L.) çeşit ve hatlarının Karadeniz koşullarında verim ve kalite özelliklerinin belirlenmesi. AÜZF Tarım Bil. Der. 2005, 11, $257-262$.

22. Mut, Z.; Aydin, N.; Bayramoglu, H.O.; Ozcan, H. Investigation of yield and primary quality characteristics of some bread wheat (Triticum aestivum L.) genotypes. J of Fac Agric OMU. 2007, 22, 193- 201.

23. Tayyar, S.; Gül, M.K. (2008). Evaluation of 12 bread wheat varieties for seed yield and some chemical properties grown in Northwestern Turkey. Asian J Chem. 2008, 20, 3715-3725.

24. Kitterman, J.S.; Rubenthaler, G.L. (1971). Assessing the quality of early generation wheat selection with the Micro AWRC Test. Cereal Sci Today. 1971, 16, 313-316.

25. Elgün, A.; Türker, S.; Bilgiçli, N. Tahıl ve Ürünlerinde Analitik Kalite Kontrolü, Selçuk Üniv. Zir. Fak. Gıda Müh. Böl. 2001, Konya, Turkey.

26. Dogan, S.; Ugur, T. Van ve çevresinde yetistirilen bazı bugdayların bisküvilik kalitesi üzerine bir arastırma. Yüzüncü Yıl Üniv Zir Fak Tarım Bil Der. 2005, 15, 139-148.

27. Indrani, D.; Venkateswara Rao, G. (2007). Rheological characteristics of wheat flour dough as influenced by ingredients of parotta. J Food Eng. 2007, 79, 100-105.

28. Başaran, A.; Göçmen, D. The effects of low mixing temperature on dough rheology and bread properties. Eur Food Res Techn. 2003, 2, 138-142.

29. Gül, H.; Özer, M.S.; Dizlek, H. Improvement of the wheat and corn bran bread quality by using glucoseoxidase and hexoseoxidase. J Food Qual. 2009, 32, 209-223. 
30. Alava, J.M.; Sahi, S.S.; Garcia-Alvarez, J.; Turob, A.; Chavez, J.A.; Garcıa, M.J.; Salazar, J. Use of ultrasound for the determination of flour quality. Ultrasonics, 2007, 46, 270-276.

31. Salazar-Garcıa, M.G.; Torres, P.I.; Reyes-Moreno, C.; Ramirez-Wong, B. Extensional flow studies on wheat flour dough swith different protein content. J Text Stu. 2003, 34, 449-464.

32. Færgestad, E.M.; Molteberg, E.L.; Magnus, E.M. Interrelationships of protein composition, protein level, baking process and the characteristics of hearth bread and pan bread. J Cereal Sci. 2000, 31, 309-320.

33. Sahari, M.A.; Gavlighi, H.A.; Tabrizzad, M.H.A. Classification of protein content and technological properties of eighteen wheat varieties grown in Iran. Int J Food Sci Techn. 2006, 41, 6-11.

34. Serna-Saldivar, S.O. "Quality Control of Cereal Grains and Their Products.” Cereal Grains: Properties, Processing, and Nutritional Attributes, CRC Press, Taylor \& Francis Group, LLC, 2010, pp. 470-497.

35. Collar, C.; Bollain, C.; Rosell, C.M. Rheological behaviour of formulated bread doughs during mixing and heating. Food Sci Techn Int. 2007, 13, 99-107.

36. Banu, I.; Stoenescu, G.; Ionescu, V.; Aprodu, I. Estimation of the baking quality of wheat flours based on rheological parameters of the Mixolab curve. Czech J. Food Sci. 2011, 29 ,35-44.

37. Codină, G.G.; Mironeas, S.; Mironeasa, C. Variability and relationship among Mixolab and Falling Number evaluation based on influence of fungal alpha-amylase addition. J Food Sci Agr. 2012, 92, 2162-2170.

38. Mironeasa, S.; Codina, G.G.; Mironeasa, C. The effects of wheat flour substutition with grape seed flour on the reological parameters of the dough assessed by Mixolab. J Texture Stud. 2012, 43, 40-48.

39. Mastilovic,' J.; Kevrešan, Ž.; Torbica, A.; Janić Hajnal, E.; Živančev, D. Prediction of traditionally utilised wheat dough technological quality parameters from Mixolab values: development and evaluation of regression models. Int J Food Sci Techn. 2014, 49, 2685-2691.

40. Kang, T.Y.; Sohn, K.H.; Yoon, M.R.; Lee, J.S.; Ko, S. Effect of the shape of rice starch granules on flour characteristics and gluten-free bread quality. Int J Food Sci Tech. 2015, 50, 1743-1749.

41. Bonet, A.; Blaszczak, W.; Rosell, C.M. Formation of homopolymers and heteropolymers between wheat flour and several protein sources by transglutaminase-catalyzed cross-linking. Cereal Chem. 2006, 83, 655-662.

42. Rosell, C.M.; Collar, C.; Haros, M. Rheological properties of wheat flour substitutes/alternative crops assessed by Mixolab. Food Hydrocol.2007, 21, 452-462.

43. Švec, I.; Hrušková, M. The Mixolab parameters of composite wheat/hemp flour and their relation to quality features. LWT - Food Sci Tech. 2015, 60, 623-629.

44. Szafranska, A. (2010). Prognozowanıe jakoscı makı pszennej na podstawıe parametrów oceny jakoscı sruty za pomoca aparatu miksolab. Prace Instytutów i Laboratoriów Badawczych Przemyslu Spozywczego t. 65.

45. Kaplan Evlice, A.; Pehlivan, A.; Külen, S.; Keçeli, A.; Şanal, T.; Karaca, K.; Salantur, A. Ekmeklik buğday ( Triticum aestivum L.) genotiplerinde ekmek hacmi ve bazı kalite parametreleri arasındaki ilişkilerin incelenmesi. Tarla Bit. Mer Araş Ens Der. 2016, 25, 12-18. 
46.Tayyar, Ş. (2008). Ekmeklik buğday çeşitlerinde dane verimi ve ekstensograf özellikleri üzerinde bir araştırma. Akdeniz Univ J Fac Agr. 2008, 21, 79-84. 